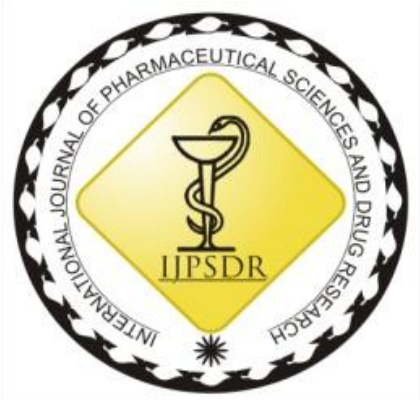

ISSN: 0975-248X

RESEARCH ARTICLE CODEN (USA): IJPSPP $(\mathrm{cc})$ EY-NG-SA

\title{
Effect of Ethanolic Extract of Fruits of Eriobotrya japonica on Lipid Profile and Body weight in Streptozotocin Induced Diabetic Rats
}

\author{
Sabeeha Shafi*, Nahida Tabassum \\ Department of Pharmaceutical Sciences, University of Kashmir, Hazratbal, Srinagar, Kashmir, Jammu \& Kashmir, India \\ Copyright (C) 2019 Sabeeha Shafi et al. This is an open access article distributed under the terms of the Creative Commons Attribution- \\ NonCommercial-ShareAlike 4.0 International License which allows others to remix, tweak, and build upon the work non-commercially, as long as \\ the author is credited and the new creations are licensed under the identical terms.
}

\begin{abstract}
Eriobotrya japonica locally called as loquat in Kashmir has been studied in various parts of the world but little work has been reported on Kashmiri loquat. The chemical nature of fruits and vegetables offers a great diversity of biological properties and plays an important role in the field of pharmacology. There is a quest for newer drugs with few adverse effects and this poses a challenge for the development of new drugs. The study was undertaken to study the activities of ethanolic extract of Eriobotrya japonica fruits in streptozotocin induced diabetic rats. The phytochemical screening of the plant was also done. The animals were divided into five groups. Normal Control group received only the vehicle. Toxic group included those animals in which diabetes was induced by streptozotocin. The $3^{\text {rd }}$ group was those animals which received streptozotocin and standard antidiabetic drugglibenclamide. $4^{\text {th }}$ group included those diabetic animals which received $50 \mathrm{mg} / \mathrm{kg}$ b.w dose of fruits of Eriobotrya japonica. $5^{\text {th }}$ group animals included those diabetic animals which received $100 \mathrm{mg} / \mathrm{kg}$ b.w of the plant extract. The biochemical parameters that were evaluated were blood glucose levels and lipid profile tests. The body weight was also checked. Histopathology of pancreas was also done. The results showed significant decrease in blood glucose levels, lipid profile tests in animals treated with different doses of the plant extracts. Histopathology of pancreas also showed positive results.
\end{abstract}

Keywords: Eriobotrya japonica fruits, blood glucose levels, lipid profile, histopathology.

DOI: 10.25004/IJPSDR.2019.110101

Int. J. Pharm. Sci. Drug Res. 2019; 11(1): 01-06

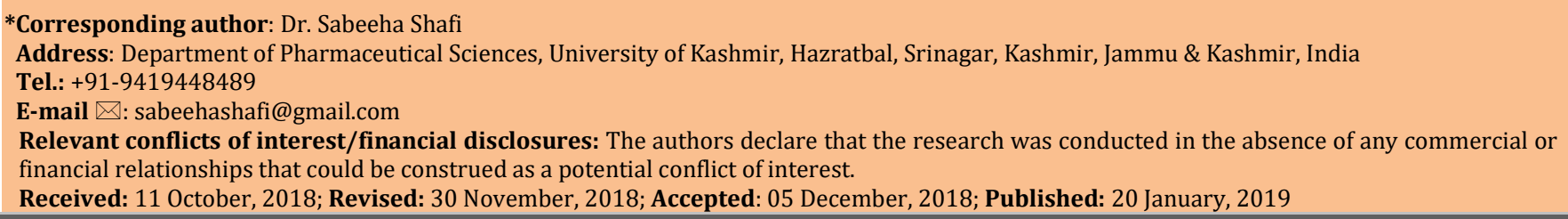

\section{INTRODUCTION}

Diabetes mellitus has been defined as metabolic disease with hyperglycaemia which leads to many complications like diabetic neuropathy, diabetic nephropathy, diabetic retinopathy and many other complications. WHO defines the disease as the $7^{\text {th }}$ cause of death in 2030 (WHO 2016). About 180 million people across the globe have type 2 DM characterized by hyperglycaemia that affects eyes, nerves, kidney and may lead to risk linked with cardiovascular disease. Diabetes mellitus is a major degenerative disease in the world today affecting at least 15 million people. ${ }^{[1]}$ It is a multifactorial disease which is characterized by hyperglycemia, lipoprotein abnormalities, raised basal 
metabolic rate, defect in reactive oxygen species scavenging enzymes and high oxidative stress induced damage to pancreatic beta cells. It is ranked third among the leading causes of death when its fatal complications are taken into account. Today in India alone there are more than 4.00 crore diabetics and the number is going to be around 9.00 crore by 2030. [2]

Many efforts are ongoing to understand and manage diabetes mellitus because the disease and disease related complications are increasing day by day. In spite of presence of large number of medicines in the pharmaceutical market, remedies from medicinal plants are used with success to treat and this disease. India has 45,000 plant species and several thousand have medicinal properties. Studies have shown that more than 800 plant species have anti- diabetic activity. These days there has been great demand for plant products due to low cost, easy availability and lesser side effects. For this plant materials are continuously scrutinized and explored for their effect as antidiabetic agents and for other complications related to diabetes. [3-10]

One of the plants is Eriobotrya japonica locally known as loquat, has been used since olden medicinal uses. The leaves are of great importance and have been used to treat nausea, vomiting times in the ethno medicine for treating diseases. It is an evergreen tree having many, belching, hiccups and gastro-intestinal disorders. The flowering period of this plant is from April to June. Although it is native to China and Japan, it grows in many parts of the world including India. One variety is found in Kashmir also. The reported bioactive compounds include flavonoids, triterpenic acids, carotenoids, volatile compounds which attribute to aroma, oleanolic acid and unsolid acid. The reported pharmacological activities include anti-oxidant, antimutagenic, anti-viral, hypolipidemic, antiinflammatory and other activities. [11-22] The present study focused on the fruits of Eriobotrya japonica on which very little work has been done. The present study was aimed to investigate its effect on body weight in diabetes and hypolipidemic activity of ethanolic extract of Eriobotrya japonica fruit in streptozotocin induced diabetic rats, because diabetes mellitus affects many parts of the human body.

\section{MATERIALS AND METHODS}

\section{Plant Material}

The ripe fruits of Eriobotrya japonica (family Rosacea) were collected from Shalimar area of the district, Srinagar, during the months of April to June and authenticated by a plant taxonomist in the Centre of Plant Taxonomy, University of Kashmir, Srinagar. The identification was done on the basis of the characters described by Kirtikar and Basu, 1935. A sample of the plant material was deposited in the herbarium of the Department of Taxonomy, University of Kashmir under voucher specimen number 1012(KASH) dated 15-09-2008 for future reference. The plant material was dried in a well-ventilated room with outside temperature ranging between 18 to $32^{\circ} \mathrm{C}$.

Preparation of the extract

The fruits were coarsely powdered and $500 \mathrm{~g}$ of the material was allowed to macerate for 48 hours with $50 \%$ ethanol, with occasional shaking. After 48 hours, the ethanolic extract was filtered through Whatman filter paper. The plant material was then macerated again with fresh $50 \%$ ethanol and the filtrate obtained from the first and the second maceration was then combined and the solvent was recovered. After the recovery of alcohol, the extract was then evaporated to dryness and the yield was noted. The extract was refrigerated at $4^{\circ} \mathrm{C}$ for future use in experimental studies.

\section{Phytochemical Screening [23-25]}

The extract obtained was subjected to qualitative tests for identification of different phytoconstituents like alkaloids, tannins, saponins, glycosides, phenolics, terpenes, flavonoids, carbohydrates, proteins and steroids, by using standard and simple qualitative methods as described by Trease and Evans.

Pharmacological Study [26]

\section{Animals}

Healthy albino rats of either sex weighing about 180$210 \mathrm{~g}$ were used during the study. The animals were procured from Central Animal House, IIIM (Indian Institute of Integrative Medicine) Jammu \& were housed in clean polypropylene cages. Before initiation of experiment, the rats were acclimatized for a period of 7 days. Standard environmental conditions such as temperature ranging from 18 to $32^{\circ} \mathrm{C}$, relative humidity (70\%) and 12 hours dark/light cycle were maintained in the quarantine. All the animals were fed with rodent pellet diet (Ashirwad Industries) and water ad libitum under strict hygienic conditions. All procedures were performed in accordance to CPCSEA guidelines after approval from the Institutional Animal and Ethics Committee (IAEC) of the Department of Pharmaceutical Sciences, University of Kashmir [No. FIAEC (Pharm. Sc) APPROVAL].

\section{Induction of Diabetes}

Hyperglycaemia was induced by administering a single dose of streptozotocin (STZ) $50 \mathrm{mg} / \mathrm{kg} \mathrm{b.w.} \mathrm{It} \mathrm{was}$ freshly dissolved in $0.1 \mathrm{M}$ citrate buffer ( $\mathrm{pH} 4.5)$ and injected intraperitoneally within 15 minutes of dissolution in a vehicle volume of $0.4 \mathrm{ml}$ with $1 \mathrm{ml}$ of tuberculin syringe fitted with 24-gauge needle. Diabetes is confirmed on $3^{\text {rd }}$ day post administration of streptozotocin by estimating the fasting blood glucose concentration. During this period the animals are given free access to water. Fasting blood glucose concentration is checked by glucostrips. The rats having blood glucose levels $>250 \mathrm{mg} / \mathrm{dl}$ are separated and selected for further studies. The animals are given the following treatment in the study.

Group I. Normal Control received 2\% of gum acacia.

Group II. Diabetic Control received STZ 50 mg/kg b.w single dose i.p. 
Group III. STZ + Glibenclamide (3 mg/kg)

Group IV. STZ + Eriobotrya japonica fruits (EBJF) [50 $\mathrm{mg} / \mathrm{kg} \mathrm{b.w]}$

Group V. STZ + EBJF [100 mg/kg b.w]

This treatment was started on the same day except in normal control and diabetic control rats which lasted for a period of 15 days orally. These rats were given free access to standard diet and water during this period. Fasting blood glucose levels were estimated on $1^{\text {st }}, 4^{\text {th }}, 9^{\text {th }}$ and $15^{\text {th }}$ day of the treatment. On the $16^{\text {th }}$ day, blood samples from these animals were collected from overnight fasting animals by cardiac puncture. The diabetic rats were anaesthesized by mild ether anesthesia before cardiac puncture. The blood sample taken was kept aside for 30 minutes for clotting. By centrifuging the sample at 6000 r.p.m for 20 minutes, the serum was separated and analyzed for various biochemical parameters. At the end of the experiment, the animals were sacrificed and pancreas was taken out. Histopathology of pancreas was also done.

\section{Sample Collection}

The blood sample of these rats were collected by pricking the tail from overnight fasted animals and blood glucose levels were estimated using One Touch Ultra strips (Johnson \& Johnson Ltd) on day $1^{\text {st }}, 4^{\text {th }}$, and $9^{\text {th }}$ day. On the $15^{\text {th }}$ day, blood was collected from overnight fasted animals under ether anesthesia by cardiac puncture, which was kept aside for $30 \mathrm{~min}$ for clotting. By centrifuging the sample at $6000 \mathrm{rpm}$ for 20mins, the serum was separated and analyzed for various biochemical parameters.

\section{Statistical Analysis}

The data which was obtained from the biochemical estimations was expressed as Mean \pm SEM for each group. The statistical analysis was carried out using one-way analysis of variance (ANOVA) followed by student $\mathrm{t}$ test. Values $p>0.05$ were considered nonsignificant, $p<0.05$ as significant, $\mathrm{p}<0.01$ as highly significant and $p<0.001$ as very highly significant respectively.

The biochemical parameters were estimated as per the following methods [27-33]

i. Serum glucose levels (Recorded on day 1, day 4, day 9 and day 15) [28-29]

ii. Serum Lipid profile (Recorded on day $15^{\text {th }}$ )

Besides this Average Body Weight of the animals was also checked Histopathology of Pancreas was also done [34-35]

\begin{tabular}{ccc}
\multicolumn{2}{c}{ Table 1: Phytochemical Results of Eriobotrya japonica fruits } \\
\hline S. No & Phytoconstituents & Results \\
\hline 1 & Tannins & - \\
2 & Alkaloids & + \\
3 & Proteins & - \\
4 & Glycosides & + \\
5 & Terpenes & - \\
6 & Phenolics & - \\
7 & Flavonoids & + \\
8 & Carbohydrates & + \\
9 & Saponins & - \\
10 & Steroids & - \\
\hline
\end{tabular}

\section{RESULTS AND DISCUSSION}

Physical Characteristics and Percentage Yield of the Ethanolic extract of Eriobotrya japonica fruits

Weight of the dried whole plant taken $=500$ grams

Weight of the extract obtained $=150$ grams

$\%$ yield $=\underline{\text { Weight of the extract obtained }} \times 100$

Weight of the dried whole plant taken

$\%$ age yield of the ethanolic extract $=30 \%$

$\begin{array}{llll}\text { Extract } & \text { Colour } & \text { Odour } & \% \text { Extractive value } \\ 50 \% & \text { Dark } & \text { Characteristic } & 30 \% \\ \text { Ethanolic } & \text { Brown } & & \end{array}$

Streptozotocin has been the usual substance used for the induction of diabetes mellitus apart from alloxan. It has shown a destructive effect of the beta cells of the pancreas. It causes a massive reduction in insulin release by the destruction of beta-cells of the islets of Langerhans thereby inducing hyperglycemia- Insulin deficiency leads to various metabolic alterations in the animals viz increased blood glucose. Diabetes mellitus has been classified as metabolic disorder characterized by resistance in the action of insulin, insufficient insulin recreation or both. It is one of the most common diseases of the world. Nowadays Type II diabetes in young has increased 30 -fold over the last 20 years concomitant with increase in obesity. Recent studies have revealed that all incidences of diabetes in this young age group are $2.5 \%$ and alarmingly $25 \%$ of their young adults have abnormalities of blood glucose. [37-38] Herbal plants have received greater attention as an alternative to conventional therapy. The demand for these remedies has currently increased. Experimental screening method is imperative in order to establish the safety and efficacy of traditional and herbal products and also to set up the active components of the herbal products. The Indian indigenous drugs have great importance both from professional and economic point of view. A large number of plants have been reported to possess anti-diabetic activity e.g., Aconitum napeilus, Aloe vera, Carum carvi, Cichorium intybus, Allium cepa, Aralia cachemirica, Allium sativum, Momordia charantia.

Table 2: Effect of ethanolic extract of Eriobotrya japonica fruits (EBJF) on Blood Glucose Levels $(\mathrm{mg} / \mathrm{dl})$ against Streptozotocin induced diabetes mellitus in rats.

\begin{tabular}{|c|c|c|c|c|c|}
\hline \multirow{2}{*}{ Groups } & \multirow{2}{*}{ Treatment } & \multicolumn{4}{|c|}{ Blood Glucose Levels(mg/dl) } \\
\hline & & DAY 1 & DAY 4 & DAY 9 & DAY15 \\
\hline I & $\begin{array}{c}\text { Normal control } \\
0.2 \mathrm{ml} \text { of } 2 \% \\
\text { gum acacia }\end{array}$ & $\begin{array}{r}80.83 \\
\pm 3.63\end{array}$ & $\begin{array}{l}79.58 \\
\pm 3.37\end{array}$ & $\begin{array}{l}80.26 \pm \\
3.96 \\
\text { (NS) }\end{array}$ & $\begin{array}{l}77.62 \pm \\
4.96 \\
\text { (NS) }\end{array}$ \\
\hline II & $\begin{array}{l}\text { Diabetic control } \\
0.2 \mathrm{ml} \text { of } 2 \% \\
\text { gum acacia }\end{array}$ & $\begin{array}{l}200.48 \\
\pm 2.89\end{array}$ & $\begin{array}{l}200.24 \\
\pm 3.67\end{array}$ & $\begin{array}{c}206.76 \\
\pm 3.23 \\
\text { (NS) }\end{array}$ & $\begin{array}{l}207.50 \pm \\
2.97 \\
\text { (NS) }\end{array}$ \\
\hline III & $\begin{array}{l}\text { STZ+ Std drug } \\
\text { Glibenclamide (3 } \\
\text { mg/kg. b.w) }\end{array}$ & $\begin{array}{l}220.85 \\
\pm 2.37\end{array}$ & $\begin{array}{l}201.98 \\
\pm 6.58\end{array}$ & $\begin{array}{c}158.71 \\
\pm \\
4.04^{* *}\end{array}$ & $\begin{array}{l}129.56 \pm \\
12.97^{* *}\end{array}$ \\
\hline IV & $\begin{array}{c}\mathrm{STZ}+\mathrm{EBJF}(50 \\
\mathrm{mg} / \mathrm{kg} \text { b.w })\end{array}$ & $\begin{array}{l}215.50 \\
\pm 2.09\end{array}$ & $\begin{array}{l}184.83 \\
\pm 1.91\end{array}$ & $\begin{array}{c}167.98 \\
\pm \\
3.06^{* *}\end{array}$ & $\begin{array}{l}152.06 \pm \\
4.36^{* * *}\end{array}$ \\
\hline V & $\begin{array}{c}\mathrm{STZ}+\mathrm{EBJF}(100 \\
\mathrm{mg} / \mathrm{kg} \text { b.w })\end{array}$ & $\begin{array}{l}225.27 \\
\pm 1.98\end{array}$ & $\begin{array}{l}202.59 \\
\pm 4.19\end{array}$ & $\begin{array}{c}176.92 \\
\pm \\
3.82^{* *}\end{array}$ & $\begin{array}{c}136.65 \pm \\
2.37^{* * *}\end{array}$ \\
\hline
\end{tabular}


Sabeeha Shafi et al. / Effect of Ethanolic Extract of Fruits of Eriobotrya japonica on Lipid Profile.......

Table 3: Effect of ethanolic extract of Eriobotrya japonica fruits on lipid profile in streptozotocin induced diabetic rats.

\begin{tabular}{|c|c|c|c|c|c|}
\hline $\begin{array}{c}\text { Grou } \\
\mathrm{p}\end{array}$ & Treatment & $\begin{array}{c}\text { Serum } \\
\text { total } \\
\text { Cholester } \\
\text { ol } \\
\mathrm{mg} / \mathrm{dl} \\
\end{array}$ & $\begin{array}{c}\text { Serum } \\
\text { triglyceri } \\
\text { de } \\
\mathrm{mg} / \mathrm{dl}\end{array}$ & $\begin{array}{c}\text { Serum } \\
\text { HDL } \\
\text { Cholester } \\
\text { ol } \\
\text { mg/dl } \\
\end{array}$ & $\begin{array}{c}\text { Serum } \\
\text { LDL } \\
\text { Cholester } \\
\text { ol } \\
\text { mg/dl } \\
\end{array}$ \\
\hline & Normal & & & & \\
\hline I & $\begin{array}{l}\text { Control } \\
(0.2 \mathrm{ml} \text { of } \\
2 \% \text { gum } \\
\text { acacia) }\end{array}$ & $\begin{array}{c}88.22 \pm \\
2.01\end{array}$ & $\begin{array}{c}76.71 \pm \\
3.45\end{array}$ & $\begin{array}{c}33.07 \pm \\
2.15\end{array}$ & $\begin{array}{c}42.51 \pm \\
2.35\end{array}$ \\
\hline II & $\begin{array}{c}\text { Diabetic } \\
\text { control } \\
\text { (STZ) }\end{array}$ & $\begin{array}{c}195.18 \pm \\
3.54^{* * *}\end{array}$ & $\begin{array}{c}193.01 \pm \\
4.84^{* * *}\end{array}$ & $\begin{array}{l}18.88 \pm \\
2.62^{* * *}\end{array}$ & $\begin{array}{l}87.02 \pm \\
3.07^{* * *}\end{array}$ \\
\hline & STZ + Std & & & & \\
\hline III & $\begin{array}{c}\text { Antidiabetic } \\
\text { drug } \\
\text { Glibenclami } \\
\text { de }(3 \\
\mathrm{mg} / \mathrm{kg})\end{array}$ & $\begin{array}{c}193.34 \pm \\
5.69\end{array}$ & $\begin{array}{c}186.96 \pm \\
4.31\end{array}$ & $\begin{array}{c}19.75 \pm \\
1.95\end{array}$ & $\begin{array}{c}86.26 \pm \\
3.02\end{array}$ \\
\hline IV & $\begin{array}{l}\text { STZ +EBJF } \\
(50 \mathrm{mg} / \mathrm{kg})\end{array}$ & $\begin{array}{c}161.46 \pm \\
2.66\end{array}$ & $\begin{array}{c}159.90 \pm \\
5.68\end{array}$ & $\begin{array}{c}22.65 \pm \\
0.77\end{array}$ & $\begin{array}{c}92.56 \pm \\
2.52\end{array}$ \\
\hline V & $\begin{array}{c}\text { STZ+EBJF } \\
(100 \mathrm{mg} / \mathrm{kg})\end{array}$ & $\begin{array}{c}132.92 \pm \\
4.63\end{array}$ & $\begin{array}{c}124.95 \pm \\
5.68\end{array}$ & $\begin{array}{c}30.37 \pm \\
3.95\end{array}$ & $\begin{array}{c}75.01 \pm \\
2.58\end{array}$ \\
\hline
\end{tabular}

STZ Dissolved in $0.1 \mathrm{M}$ citrate buffer at a. dose of $50 \mathrm{mg} / \mathrm{kg}$ b.w and injected i.p single dose. Diabetes confirmed on third day post administration of streptozotocin. Standard drug Glibenclamide \& plant given as ethanolic extracts were administered orally for 15 days, in a single dose daily after confirmation of hyperglycaemia $\mathrm{n}=6$ (Number of animals in each group)

Group II is compared with Group I and all other groups are compared with group II. ${ }^{* * *} p<0.001$ Very highly significant; ${ }^{* *} p<$ 0.01; Highly significant; * $p<0.05$ significant $p>0.05$ Non-significant.

Table 4: Effect of ethanolic extract of Eriobotrya japonica fruits (EBJF) on Average Body Weight (grams) against Streptozotocin induced diabetes mellitus in rats

\begin{tabular}{|c|c|c|c|c|c|}
\hline \multirow{2}{*}{ Groups } & \multirow{2}{*}{ Treatment } & \multicolumn{4}{|c|}{ Average Body weight ( in grams) } \\
\hline & & DAY 1 & DAY 4 & DAY 9 & DAY 15 \\
\hline I & $\begin{array}{c}\text { Normal } \\
\text { control } \\
0.2 \mathrm{ml} \text { of } 2 \% \\
\text { gum acacia }\end{array}$ & $\begin{array}{l}250.58 \\
\pm 8.14\end{array}$ & $\begin{array}{l}253.90 \\
\pm 9.93\end{array}$ & $\begin{array}{c}262.12 \pm \\
10.47 \\
(\mathrm{NS})\end{array}$ & $\begin{array}{c}267.23 \pm \\
13.09 \\
(\mathrm{NS})\end{array}$ \\
\hline II & $\begin{array}{c}\text { Diabetic } \\
\text { control } \\
0.2 \mathrm{ml} \text { of } 2 \% \\
\text { gum acacia }\end{array}$ & $\begin{array}{l}205.83 \\
\pm 7.64\end{array}$ & $\begin{array}{l}202.16 \\
\pm 6.61\end{array}$ & $\begin{array}{c}175.56 \pm \\
6.77^{* *}\end{array}$ & $\begin{array}{c}158.8 \pm \\
7.51^{* *}\end{array}$ \\
\hline III & $\begin{array}{c}\text { STZ + Std } \\
\text { drug } \\
\text { Glibenclamide } \\
(3 \mathrm{mg} / \mathrm{kg} . \\
\text { b.w })\end{array}$ & $\begin{array}{l}203.17 \\
\pm 4.91\end{array}$ & $\begin{array}{l}200.67 \\
\pm 4.94\end{array}$ & $\begin{array}{c}180.92 \pm \\
7.63^{*}\end{array}$ & $\begin{array}{c}160.00 \pm \\
8.69^{* *}\end{array}$ \\
\hline VI & $\begin{array}{c}\text { STZ + EBJF } \\
(50 \mathrm{mg} / \mathrm{kg} \\
\text { b.w })\end{array}$ & $\begin{array}{r}240.13 \\
\pm 9.15\end{array}$ & $\begin{array}{l}237.13 \\
\pm 9.17\end{array}$ & $\begin{array}{c}228.80 \pm \\
12.58^{*}\end{array}$ & $\begin{array}{c}222.12 \pm \\
13.83^{* *}\end{array}$ \\
\hline VII & $\begin{array}{c}\text { STZ + EBJF } \\
(100 \mathrm{mg} / \mathrm{kg} \\
\text { b.w })\end{array}$ & $\begin{array}{l}223.87 \\
\pm 6.71\end{array}$ & $\begin{array}{l}230.42 \\
\pm 5.76\end{array}$ & $\begin{array}{c}238.80 \pm \\
4.76^{*}\end{array}$ & $\begin{array}{c}245.50 \pm \\
4.27^{* *}\end{array}$ \\
\hline
\end{tabular}

STZ Dissolved in 0.1M citrate buffer at a. dose of $50 \mathrm{mg} / \mathrm{kg}$ b.w and injected i.p. single dose Diabetes confirmed on third day post administration of streptozotocin. Standard drug Glibenclamide \& three plants given as $50 \%$ ethanolic extracts were administered orally for 15 days, in a single dose daily after confirmation of hyperglycaemia. $\mathrm{n}=6$ (Number of animals in each group)

DAY 1 compared with DAY $15{ }^{*} p<0.05$ significant; ${ }^{* *} p<0.01$ highly significant; ${ }^{* * *} p<0.001$ very highly significant; $p>0.05$ non-significant ( NS)

Rats weighing in the range of $180-210 \mathrm{~g}$ were procured from IIIM Jammu and kept in polypropylene cages under uniform conditions of food, water, temperature and degree of nursing care. It was ensured that the animals were in good health. These animals were free from diseases. Male and female animals were kept in separate cages so that there was no interference in evaluation of biochemical parameters during the period of study. The temperature and the humidity were in the range of $15-25^{\circ} \mathrm{C}$ and $70-75 \%$ respectively.

The phytochemical investigation of ethanolic extract of fruits of Eriobotrya japonica carried out by standard procedures revealed the presence of alkaloids, flavanoids, glycosides and carbohydrates (Table 1).

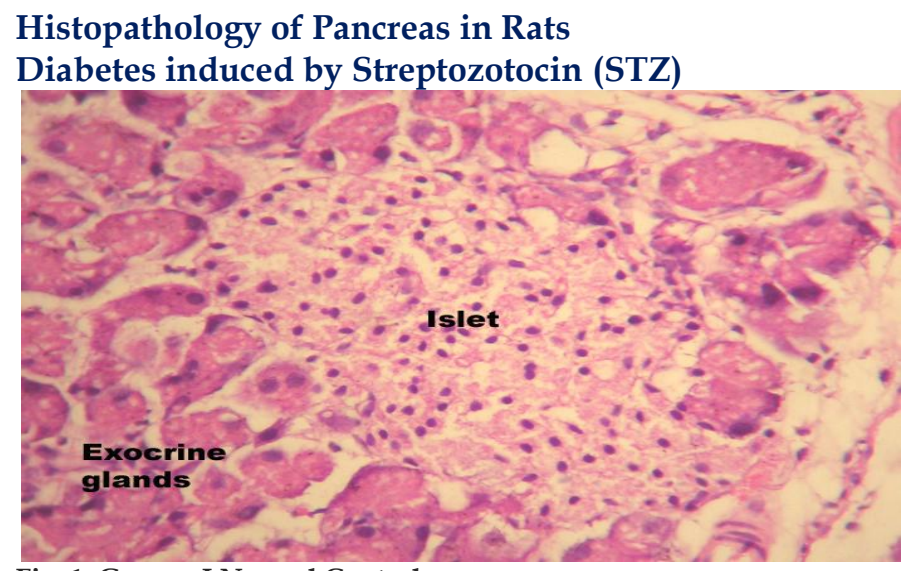

Fig. 1: Group -I Normal Control

Pancreas of rats showing a large islet structure surrounded by exocrine gland tissue. No inflammatory cells are seen in the islet (H\&E x 40X)

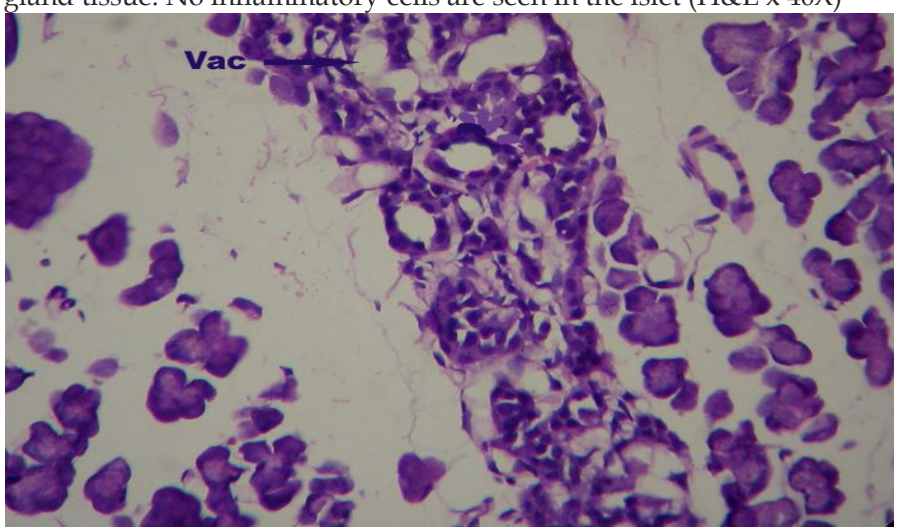

Fig. 2 (a): Group-II - Diabetic Control

Pancreas from diabetic rats showing a islet structure surrounded by exocrine gland tissue. There is vacuolation of the islet cells and lymphocytic infiltration into the islet. (H\&E x 40X)

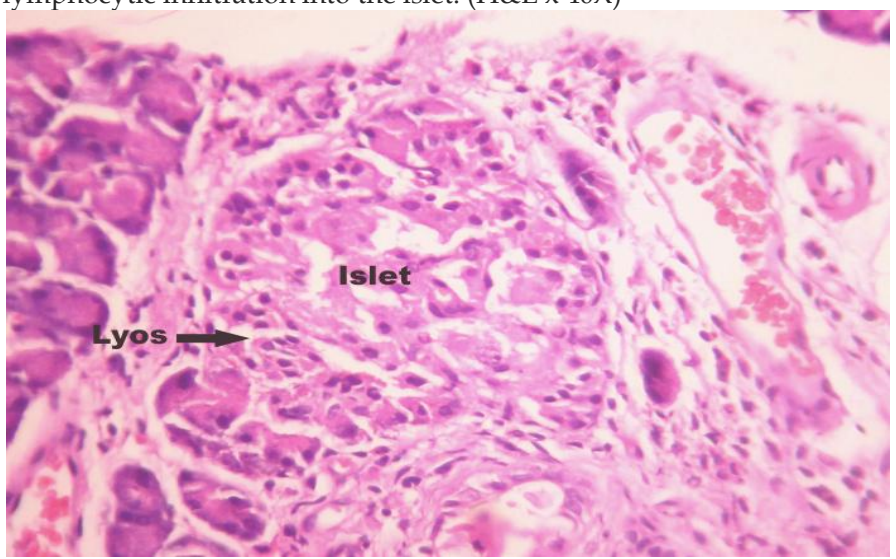

Fig. 2 (b): Group-II - Diabetic Control

Pancreas from diabetic rats showing a islet structure surrounded by exocrine gland tissue. There is vacuolation of the islet cells and lymphocytic infiltration into the islet. (H\&E x 40X) 


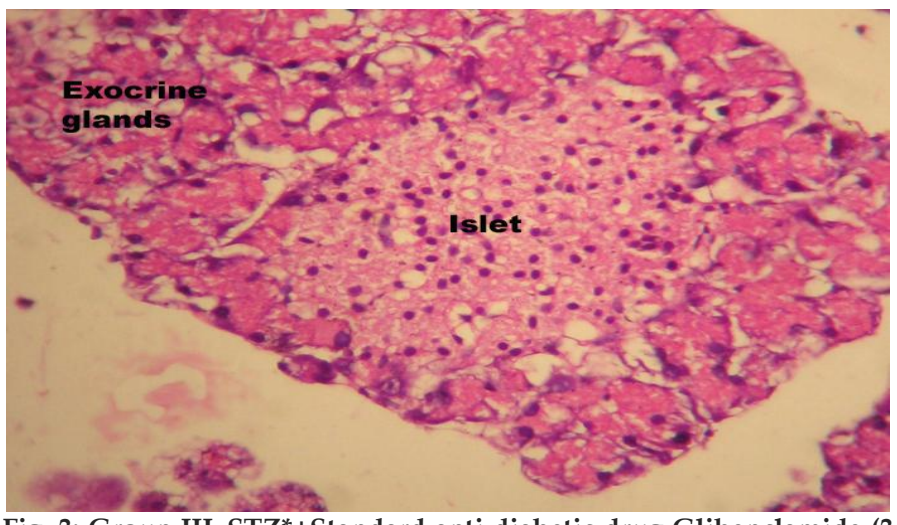

Fig. 3: Group III-STZ*+Standard anti diabetic drug Glibenclamide (3 $\mathrm{mg} / \mathrm{kg}$ b.w)

Pancreas from diabetic rats showing a large islet structure surrounded by exocrine gland tissue with no vacuolation. No inflammatory cells are seen in the islet (H\&E x 40X)

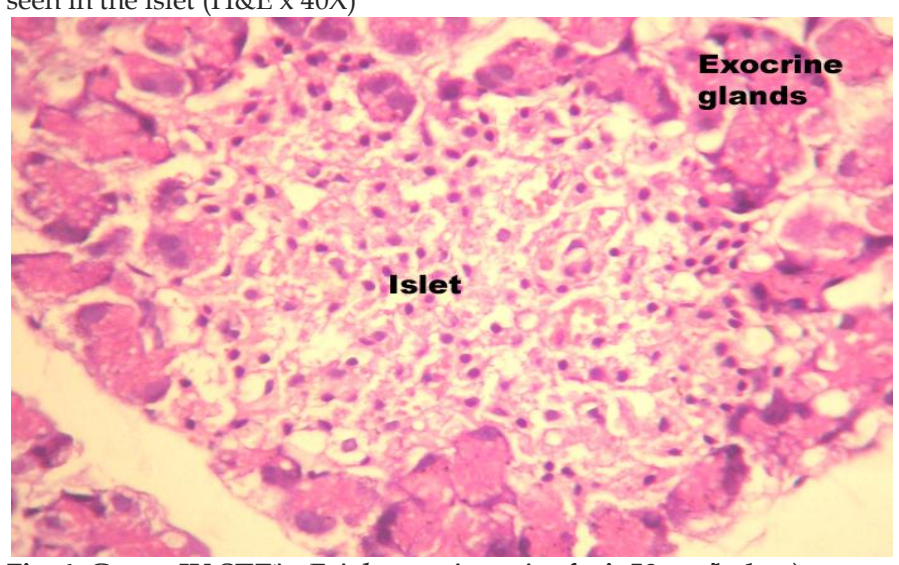

Fig. 4: Group IV STZ*+ Eriobotrya japonica fruit $50 \mathrm{mg} / \mathrm{kgb.w}$ )

Pancreas from diabetic rats showing an islet structure surrounded by exocrine gland tissue. Few inflammatory cells are seen at the margins of the islet. (H\&E $x 40 X)$

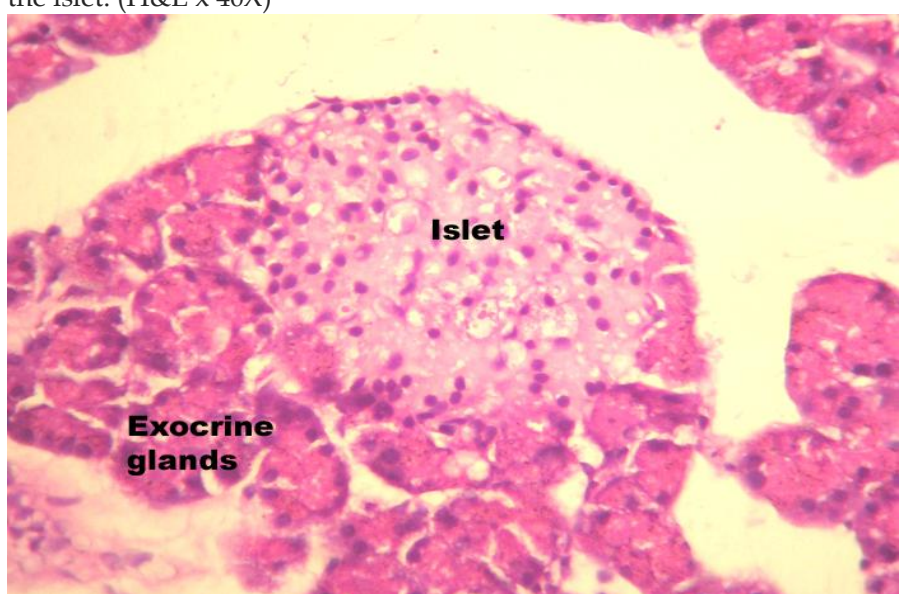

Fig. 5: Group V STZ*+ Eriobotrya japonica fruit (100 mg/kg b.w)

Pancreas from diabetic rats showing a comparatively smaller islet

structure with exocrine gland tissue seen at the lower and left edges. No inflammatory cells are seen in the islet. (H\&E x 40X)

*Streptozotocin (STZ) $(50 \mathrm{mg} / \mathrm{kg}$ ) b.w. given once i.p

The results of the present study found that ethanolic extract of Eriobotrya japonica reduced the glucose level in animals made diabetic with streptozotocin. Streptozotocin has been shown to induce free radical production and cause tissue injury. The pancreas is especially susceptible to the action of streptozotocin induced free radical damage.

In the present investigation, ethanolic extract of Eriobotrya japonica demonstrated the significant anti- diabetic and hypolipidemic activity (Table 2-4). The histopathological studies also showed positive results (Fig. 1-5). The antidiabetic effect of the ethanolic extract may be due to the enhanced secretion of insulin from the beta cells of pancreas or may be due to increased tissue uptake of glucose by enhancement of insulin sensitivity. [36-37]

The literature reports reveal that flavonoids present in the plant extract known to possess antidiabetic and hypolipidemic activity. Since many antidiabetic drugs do not correct lipidemic disorders, the observed effects of the plant extract in diabetic rats makes Eriobotrya japonica quite important in the management of diabetes. Since there is a strong well-established link between diabetes mellitus, dyslipidemia, obesity, hypertension and ischemic heart disease, effect of the plant extract on weight loss/gain needs to be explored on scientific base.

The ethanolic extract of Eriobotrya japonica fruits has beneficial effects on blood glucose levels. Further studies on pharmacological and biochemical investigations will clearly elucidate the mechanism of action and will help in projecting this plant as a therapeutic target in diabetic research. The level of morbidity and mortality because of this disease and its potential complications which are enormous, pose significant healthcare burdens on the families and society in India. It has shown tremendous increase in younger people than in an elderly people. There is an urgent need to change the lifestyle of people and inclusion of fruits and vegetables that will reduce the frequency of taking medicines in near future.

\section{ACKNOWLEDGEMENT}

We are highly thankful to Sri Krishna Drugs Ltd., C-4 Industrial Area Uppal, Hyderabad for providing a free gift pure sample of Glibenclamide which was used as standard anti diabetic drug and also to University Grants Commission for financial assistance. The Department of Pharmaceutical Sciences University of Kashmir provided facilities for carrying out this work also need appreciation.

\section{REFERENCES}

1. Alberti KG, Zimmet PZ. Definition diagnosis and classification of diabetes mellitus and its complications. Part I: Diagnosis and classification of diabetes mellitus provisional report of a WHO consultation. Diabetes Med. 1998; 15(7): 539 553.

2. King H. Diabetes mellitus: a growing international health care problem. Int Diab Monitor. 1997; 9: 1-6.

3. Grover JK, Yadav S, Vats V. Medicinal Plants of India with anti-diabetic potential. J Ethnopharmacol. 2002; 81(1): 81-100.

4. Rafiullah MRM, Siddiqui AW, Mir SR, Ali M, Pillai KK, Singh S. Antidiabetic Activity of some Indian Medicinal Plants. Pharmaceutical Biology 2006; 44(2): 95-99.

5. Rastogi RP, Mehrotra BN Compendium of Indian Medicinal Plants Vol V, New Delhi, India Publications and Information Directorate (CSIR), 1995. p, 405

6. Rastogi RP, Mehrotra BN. Compendium of Indian Medicinal Plants Vol. I, New Delhi, India, Publications and Information's Directorate (CSIR), pp, 1999 326, 398. 
7. Rastogi RP, Mehrotra BN. Compendium of India Medicinal Plants Vol II, New Delhi Publications and Information Directorate (CSIR), 1990 p, 398.

8. Rastogi RP, Mehrotra BN Compendium of Indian Medicinal Plants Vol II, New Delhi Publications and Information Directorate (CSIR), 1991. p, 660

9. Chopra RN, Nayar SL, Chopra IC. Glossary of Indian medicinal plants. CSIR Pub, New Delhi, 1966; 104.

10. Chopra RN, Chopra IC. A review of work on Indian medical plants, ICMR, New Delhi.1955.

11. Singh B, Gairola S, Kumar D, Gupta V, Bansal P. Pharmacological Potential of Eriobotrya japonica- An overview International Research Journal of Pharmacy. 2010;1(1): 95-99.

12. Chen J, Li WL, Wu JL, Ren BR, Zhang HQ. Hypoglycemic effects of a sequiterpene glycoside isolated from leaves of loquat (Eriobotrya japonica (Thumb,) Lindl. Phytomedicine. 2008; 15(1-2): 98-102.

13. El-Hossary GA, Fathy MM, Kassem HA et al. Phytochemical and biological investigations of Eriobotrya japonica growing in Egypt. Bulletin of Faculty of Pharmacy. 2000; 38:129-142

14. Huang $\mathrm{Y}, \mathrm{Li}$ J, Cao $\mathrm{Q}, \mathrm{Yu} \mathrm{SC}, \mathrm{Lv} \mathrm{XW}$, Jin $\mathrm{Y}$ et al. AntiOxidative effect of triterpene acids of Eriobotrya japonica (Thumb). Lindl. Leaf in chronic bronchitis rats. Life Science. 2006; 78: 2749-2757.

15. Ito H, Kobayashi E, Takamasto $\mathrm{Y}$, Li SH, Hatano T, Sakagami $\mathrm{H}$, et al. Polyphenols from Eriobotrya japonica and their cytotoxicity against human oral tumour cell lines. Chem Pharm Bull (Tokyo). 2000; 48(5): 687-693.

16. Yokoto J, Takuma D, Hamada A, Onogawa M, Yoshioka S, Kusenose $\mathrm{M}$ et al. Scavenging of reactive oxygen species by Eriobotrya Japonica seed extract. Biological and Pharmaceutical Bulletin, 2006; 29: 467-471.

17. Hamada A, Yoshioka S, Takuma D, Yokota J, Cui T, Kusunose $\mathrm{M}$, et al. The effect of Eriobotrya japonica seed extract on oxidative stress in adriamycin-induced nephropathy in rats. Biol and Pharm Bull. 2004; 27: 1961-1964.

18. Know HK, Kang MJ, Kim HJ, Choi JS, Paik KJ, Chung HY. Inhibition of NF kappa B by methyl chlorogenate from Eriobotrya japonica. Molecules and Cells. 2000; 10: 241-246.

19. Nishioka Y, Yoshioka S, Kusunose M, Cui T, Hamada A, Ono $\mathrm{M}$ et al. Effects of extracts derived from Eriobotrya japonica on liver function improvement in rat. Biol and Pharm Bull. 2002 ; 25: 1053-1057.

20. Shimizu M, Fukumura H, Tsuji H, Tanaami S, Hayashi T, Morita N. Anti-inflammatory constituents of topically applied crude drugs constituents and anti-inflammatory effect of Eriobotrya japonica Lindl. Chem and Pharm Bull. 1986; 34: 2614-2617.

21. Ju JH, Zhou L, Lin G, Liu D, Wang LW, Yang JS. Studies on constituents of triterpene acids from Eriobotrya Japonica and their anti-inflammatory and anti-tussive effects. J of Chinese Pharmacol. 2003; 38: 752-757.

22. Banno N, Akihisa T, Tokuda H, Yasukawa $K$, Taguchi $Y$, Akazawa $\mathrm{H}$ et al. Anti inflammatory and antitumorpromoting effects of the triterpene acids from the leaves of Eriobotrya japonica. Biol and Pharm Bull. 2005; 28: 1995-1999.

23. Harborne JB. Phytochemical methods, Chapman and Hall Ltd., London, 1973. pp. 49-188.

24. Rasool R, Ganai BA, Akbar S, Kamili AN, Masood A. Phyto chemical screening of Prunella vulgaris L. An important Medicinal Plant of Kashmir Pak. J. Pharm Sci., 2010; 23(.4): 399-402.

25. Trease GE, Evans WC. Pharmacognosy, $11^{\text {th }}$ edn., Brailliar Tiridel Can., Macmillian Publishers1989.

26. Babu V, Gangadevi T, Subramanian A. Antidiabetic activity of ethanol extract of Cassia Klenii leaf in streptozotocininduced diabetic rats and isolation of an active fraction and toxicity evaluation of the extract. Ind J of Pharmacol. 2003; 35: 290-296.

27. Varley H. Practical Clinical Biochemistry New Delhi CBS. Publishers and Distributors V edition 1980; 1: 457.

28. Trinder P. Determination of Glucose in Blood Using Glucose Oxidase with an Alternative Oxygen Acceptor. Ann Clin Biochem.1966; 6: 24-25

29. Trinder P. Glucose oxidase method. Ann Clin Biochem. 1969: 6.

30. Allain CC, Poon LS, Chan CS, Richmond W, Fu PC. CHODPAP method for determination of total cholesterol. Clin. Chem. 1974; 20: 470-475.

31. Friedewald WT, Levy RI, Frednickson DS. Estimation of the concentration of low-density lipoprotein cholesterol in Plasma, without use of the preparative ultra-centrifuge. Clin Chem. 1972; 18: 499-502.

32. Izzo C, Grillo F, Muradcer E. Improved method for determination of high density lipoprotein cholesterol. Isolation of high-density lipoprotein by use of polyethylene glycol 6000. Clin. Chem. 1981; 27: 371-374.

33. Trivedi NA, Majumder B, Bhatt JD, Hemavathi KG. Effect of Shilajit on blood glucose and lipid profile in alloxan-induced diabetic rats. Ind J Pharmacol 2004; 36(6): 373-376.

34. Bancroft JD, Srevens A, Turner DR. Theory and practice of histological Techniques, $4^{\text {th }}$ Edn (Churchill Livington, New York) 1996: 51.

35. Drury RAB, Wallington EA. Carletons histological technique, $6^{\text {th }}$ edition, Oxford university press, London 1973: 124-136.

36. Michael JF. Diabetes Treatment, Part 1: Diet and Exercise. Clin Diabetes. 2007; 25(3): 105-109.

37. Pradeep R, Mohan V. The changing scenario of the diabetes epidemic: implications for India. Indian J Med Res. 2002; 116: 121-132.

HOW TO CITE THIS ARTICLE: Shafi S, Tabassum N. Effect of Ethanolic Extract of Fruits of Eriobotrya japonica on Lipid Profile and Body weight in Streptozotocin Induced Diabetic Rats. Int. J. Pharm. Sci. Drug Res. 2019; 11(1): 01-06. DOI: 10.25004/IJPSDR.2019.110101 